\title{
Cell competition between wild-type and JAK2V617F mutant cells prevents disease relapse after stem cell transplantation in a murine model of myeloproliferative neoplasm
}

\author{
Haotian Zhang ${ }^{1}$, Melissa Castiglione ${ }^{2,3}$, Lei Zheng ${ }^{4}$ and Huichun Zhan ${ }^{2,5,6,7^{*}}$ (])
}

\begin{abstract}
Disease relapse after allogeneic stem cell transplantation is a major cause of treatment-related morbidity and mortality in patients with myeloproliferative neoplasms (MPNs). The cellular and molecular mechanisms for MPN relapse are not well understood. Here, we established a murine model of MPN relapse, in which $\sim 60 \%$ of the MPN recipient mice develop disease relapse after receiving stem cell transplantation with wild-type marrow donor. Using this model, we find that impaired wild-type cell function is associated with MPN disease relapse. We also show that competition between wild-type and JAK2V617F mutant cells can modulate the immune cell composition and PD-L1 expression induced by the JAK2V617F oncogene. These results suggest that cell competition between wild-type donor cells and JAK2V617F mutant recipient cells can prevent MPN disease relapse after stem cell transplantation.
\end{abstract}

Keywords: Myeloproliferative neoplasm, Stem cell transplantation, Relapse, Cell competition, JAK2V617F, Immune cells, PD-L1, Murine model

To the Editor.

Allogeneic stem cell transplantation is the only curative treatment for patients with myeloproliferative neoplasms (MPNs). However, disease relapse is seen in up to $40 \%$ of patients after transplantation and is a leading cause of transplant-related morbidity and mortality in these patients [1-4]. Mechanisms for why the MPN disease relapses in some patients while remains in remission in others are not well understood. The hematopoietic stem/progenitor cell (HSPC)

\footnotetext{
*Correspondence: Huichun.Zhan@stonybrookmedicine.edu

${ }^{6}$ Division of Hematology-Oncology, Department of Medicine, Stony

Brook School of Medicine, HSC T15, Room 053, Stony Brook, NY 11794, USA

Full list of author information is available at the end of the article
}

compartment in MPN is heterogeneous with the presence of both JAK2 wild-type and JAK2V617F mutant cells in most patients [5]. Recently, we reported that coexisting wild type cells can alter both the gene expression profile and cellular function of JAK2V617F mutant HSPCs and prevent the expansion of mutant cells [6]. We hypothesize that competition between the wildtype donor and JAK2V617F mutant recipient cells dictates the outcome of disease relapse versus remission after stem cell transplantation.

To test this hypothesis, we crossed JAK2V617F Flip-Flop (FF1) mice with Tie2-Cre mice to express JAK2V617F specifically in all hematopoietic cells and vascular endothelial cells (ECs) $\left(\mathrm{Tie} 2{ }^{ \pm} \mathrm{FF} 1^{ \pm}\right.$, or Tie2FF1) [7-9], so as to model the human diseases in which both the HSPCs and ECs harbor the mutation [10-12]. We original author(s) and the source, provide a link to the Creative Commons licence, and indicate if changes were made. The images or other third party material in this article are included in the article's Creative Commons licence, unless indicated otherwise in a credit line to the material. If material is not included in the article's Creative Commons licence and your intended use is not permitted by statutory regulation or exceeds the permitted use, you will need to obtain permission directly from the copyright holder. To view a copy of this licence, visit http://creativecommons.org/licenses/by/4.0/. The Creative Commons Public Domain Dedication waiver (http://creativeco mmons.org/publicdomain/zero/1.0/) applies to the data made available in this article, unless otherwise stated in a credit line to the data. 
transplanted wild-type CD45.1 marrow directly into lethally irradiated Tie2FF1 mice or Tie2-cre control mice (CD45.2) (Fig. 1A). During a 6-7mo follow up, while all wild-type control recipients displayed full donor engraftment, $\sim 60 \%$ Tie2FF1 recipient mice displayed recovery of the JAK2V617F mutant hematopoiesis (mixed donor/ recipient chimerism) 10 weeks after transplantation and developed neutrophilia and thrombocytosis, results consistent with our previous report [8] (Fig. 1B, C). Marrow $\mathrm{Lin}^{-} \mathrm{CKit}^{+} \mathrm{Sca}^{+} \mathrm{CD} 150^{+} \mathrm{CD} 48^{-}$HSCs were significantly expanded in the Tie2FF1 recipient mice with mixed chimerism (i.e., with disease relapse) compared to Tie2FF1 recipient mice with full donor engraftment (i.e., with disease remission) (Fig. 1D).

We compared wild-type and JAK2V617F mutant HSPC functions between the relapsed Tie2FF1 recipient mice and those remained in remission. We found that wild-type $\mathrm{Lin}^{-} \mathrm{CKit}^{+} \mathrm{Scal}^{+}$(LSK) HSPCs demonstrated decreased proliferation, increased apoptosis, and increased cellular senescence compared to mutant HSPCs during disease relapsed; in contrast, there was no significant difference between wild-type and mutant HSPC functions (i.e., proliferation, apoptosis, senescence) during remission (Fig. 1E-G). These findings suggest that deterioration of wild-type cell function is associated with MPN disease relapse.

To understand how co-existing wild-type cells prevent the expansion of JAK2V617F mutant HSPCs, we used a murine model of wild-type and JAK2V617F mutant cell competition we previously established [6]. In this model, when 100\% JAK2V617F mutant marrow cells are transplanted alone into lethally irradiated

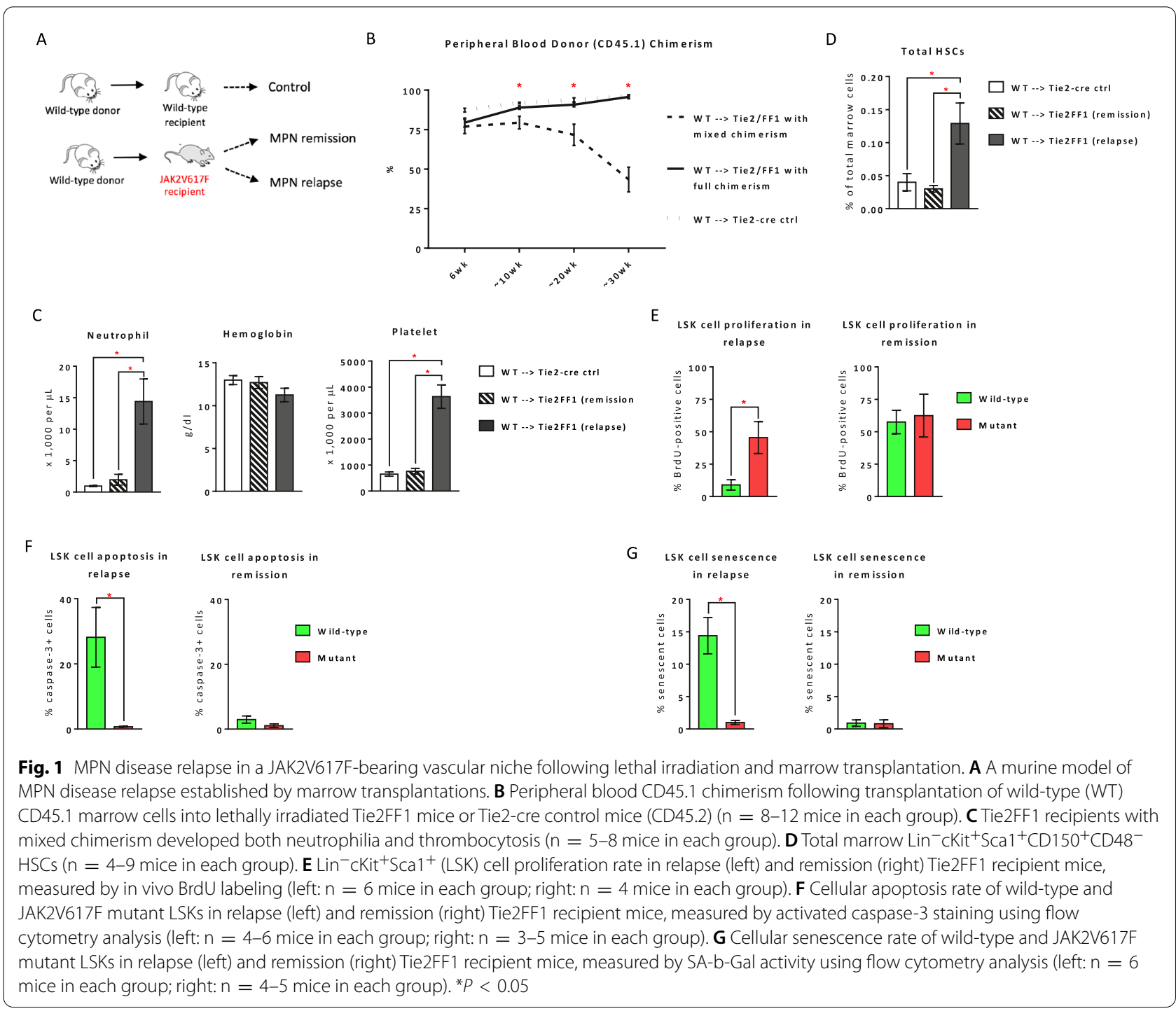


wild-type recipients, the recipient mice develop a MPN phenotype $\sim 4 \mathrm{wks}$ after transplantation; in contrast, when a 50-50 mix of mutant and wild-type marrow cells are transplanted together into lethally irradiated wild-type recipient mice, the mutant donor cells engraft to a similar level as the wild-type donor cells and the recipient mice display normal blood counts during more than 4-months of follow up [6] (Fig. 2A). Gene expression profiling revealed that gene ontology terms humoral immune response, leukocyte/B cell/T cell/ complement activation, and immune response-activated signaling transduction were highly enriched in JAK2V617F mutant $\mathrm{Lin}^{-} \mathrm{cKit}^{+} \mathrm{HSPCs}$ with cell competition compared to mutant HSPCs without competition (Fig. 2B). These results prompted us to examine various immune cell types and we found that: (1) compared to wild-type HSPCs, JAK2V617F mutant HSPCs generated significantly more $\mathrm{T}$ cells and less $\mathrm{B}$ cells in the spleen, and more myeloid-derived suppressor cells (MDSCs) in the marrow; and (2) there was no difference in $\mathrm{T}, \mathrm{B}$, or MDSC numbers between recipients of wild-type HSPCs and recipients of mixed wild-type and JAK2V617F mutant HSPCs (Fig. 2C). Similarly, we found that program death ligand 1 (PD-L1) expression was significantly upregulated on JAK2V617F mutant
LSK cells compared to wild-type LSKs; however, this PD-L1 upregulation on mutant LSKs was significantly decreased with co-existing wild-type cell competition (Fig. 2D). Taken together, these results indicate that the wild-type cells may prevent the expansion of coexisting JAK2V617F mutant cells through modulating the immune abnormality induced by the JAK2V617F mutation.

In summary, although the molecular mechanisms responsible for MPN disease relapse after stem cell transplantation remain unclear, our study provides important observations and mechanistic insights that co-existing wild-type cell competition can prevent MPN disease relapse after stem cell transplantation. Findings from our study also suggest that one possible mechanism for cell competition to prevent MPN disease relapse is that wild-type cells can help restore the immune dysregulation induced by the JAK2V617F oncogene. Results from our previous work ${ }^{6}$ and current study provide the rational to further investigate whether wild-type cells could be used as a therapeutic approach to control mutant clonal expansion in MPNs. Additional methods can be found in Additional file 1.

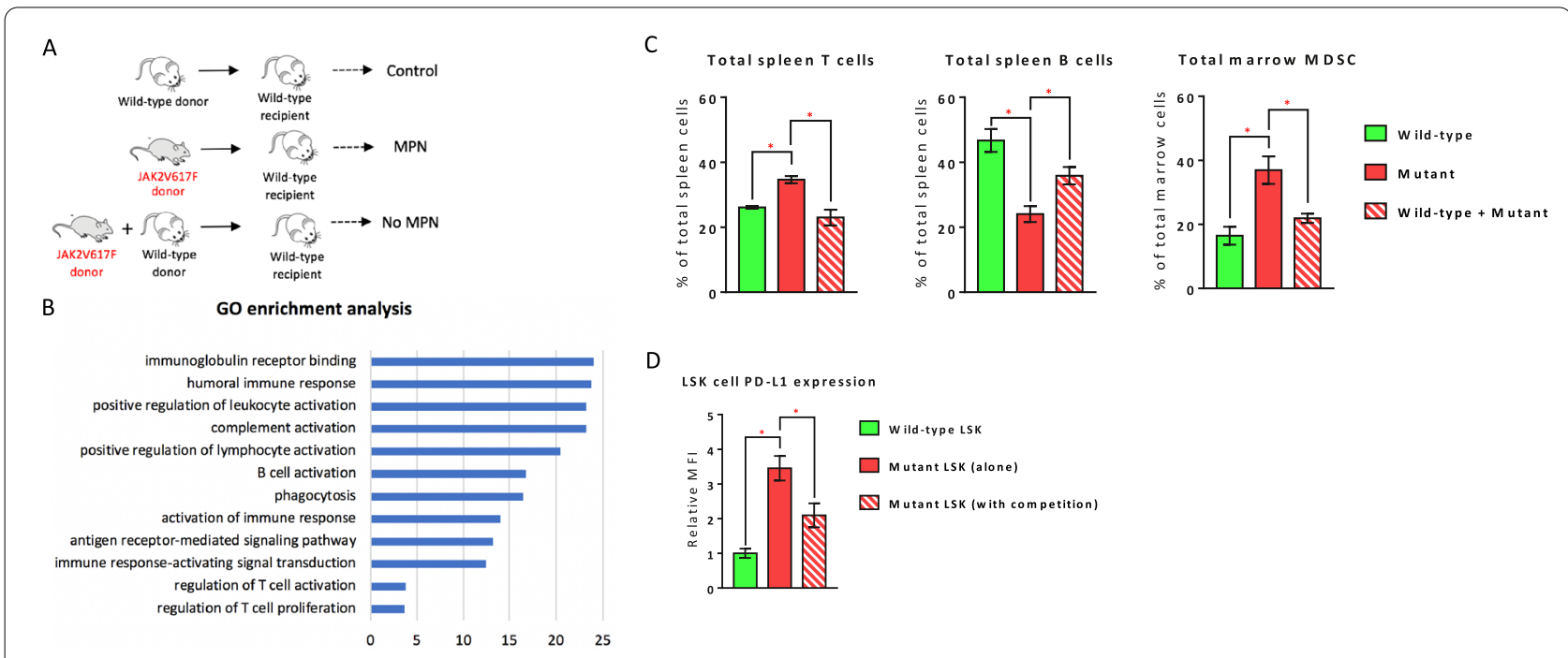

Fig. 2 Immune regulation associated with wild-type and JAK2V617F mutant cell competition. A A murine model of wild-type and JAK2V617F mutant cell competition established by marrow transplantations. B Differentially enriched Gene Ontology (GO) terms in mutant Lin $^{-} \mathrm{CKit}{ }^{+} \mathrm{HSPCS}$ transplanted together with wildtype cells (pooled sample from 3 mice) compared to mutant HSPCs transplanted alone (pooled sample from 2 mice). $P$ values are plotted as the negative of their logarithm. C Spleen T cells $\left(C D 3^{+} C D 4^{+}\right.$and $\left.C D 3^{+} C D 8^{+}\right)$and $B$ cells $\left(C D 3^{-} B 220^{+}\right)$, and marrow MDSCs (both CD11 b+Ly6ChighLy6G- M-MDSCs and CD11 b+Ly6ClowLy6G+PMN-MDSCs) in wild-type recipient of wild-type donor ("wild-type"), JAK2V617F mutant donor ("mutant"), or both wild-type and mutant donors ("wild-type + mutant") (spleen T cells: $\mathrm{n}=3$ mice in each group; spleen B cells: $n=3-6$ mice in each group; marrow MDSCs: $n=3-6$ mice in each group). $\mathbf{D}$ Quantitative measurement of mean fluorescence intensity for PD-L1 staining on wild-type LSK cells ( $n=7$ mice), JAK2V617F mutant LSK cells ( $n=4$ mice), and JAK2V617F mutant LSK cells with co-existing wild-type cell competition $\left(n=9\right.$ mice). ${ }^{*} P<0.05$ 


\section{Supplementary Information}

The online version contains supplementary material available at https://doi. org/10.1186/s40164-021-00241-2.

Additional file 1. Materials and methods.

\section{Authors' contributions}

$\mathrm{HZ}$ performed various in vitro and in vivo experiments of the project; $M C$ assisted various in vivo experiments; LZ provided scientific consultation on the immune phenotype associated with wild-type and JAK2V617F mutant cell competition; $\mathrm{HZ}$ conceived the projects, analyzed the data, interpreted the results, and wrote the manuscript. All authors read and approved the final manuscript.

\section{Funding}

This research was supported by the National Heart, Lung, and Blood Institute grant NIH R01 HL134970 (HZ) and VA Merit Award BX003947 (HZ).

\section{Availability of data and materials}

Upon request to the corresponding author.

\section{Declarations}

Ethics approval and consent to participate

Animal experiments were performed in accordance with the guidelines provided by the Institutional Animal Care and Use Committee.

\section{Consent for publication}

Not applicable.

\section{Competing interests}

The authors declare no competing interests.

\section{Author details}

${ }^{1}$ Graduate Program in Molecular and Cellular Biology, Stony Brook University, Stony Brook, NY, USA. ${ }^{2}$ Department of Medicine, Stony Brook School of Medicine, Stony Brook, NY, USA. ${ }^{3}$ Albert Einstein College of Medicine, Bronx, NY, USA. ${ }^{4}$ The Sidney Kimmel Comprehensive Cancer Center, Johns Hopkins University, Baltimore, MD, USA. ${ }^{5}$ Medical Service, Northport VA Medical Center, Northport, NY, USA. ${ }^{6}$ Division of Hematology-Oncology, Department of Medicine, Stony Brook School of Medicine, HSC T15, Room 053, Stony Brook, NY 11794, USA. ${ }^{7}$ Northport VA Medical Center, Building 62, Room 124, 79 Middleville Road, Northport, NY 11768, USA.

Received: 25 September 2021 Accepted: 7 October 2021

Published online: 19 October 2021

\section{References}

1. Kroger N. Current challenges in stem cell transplantation in myelofibrosis. Curr Hematol Malig Rep. 2015;10:344-50.

2. Kroger N, Holler E, Kobbe $\mathrm{G}$, et al. Allogeneic stem cell transplantation after reduced-intensity conditioning in patients with myelofibrosis: a prospective, multicenter study of the Chronic Leukemia Working Party of the European Group for Blood and Marrow Transplantation. Blood. 2009;114:5264-70.

3. Guardiola P, Anderson JE, Bandini G, et al. Allogeneic stem cell transplantation for agnogenic myeloid metaplasia: a European Group for Blood and Marrow Transplantation, Societe Francaise de Greffe de Moelle, Gruppo Italiano per il Trapianto del Midollo Osseo, and Fred Hutchinson Cancer Research Center Collaborative Study. Blood. 1999;93:2831-8.

4. Patriarca F, Bacigalupo A, Sperotto A, et al. Allogeneic hematopoietic stem cell transplantation in myelofibrosis: the 20-year experience of the Gruppo Italiano Trapianto di Midollo Osseo (GITMO). Haematologica. 2008;93:1514-22.

5. James C, Mazurier F, Dupont S, et al. The hematopoietic stem cell compartment of JAK2V617F-positive myeloproliferative disorders is a reflection of disease heterogeneity. Blood. 2008;112:2429-38.

6. Castiglione M, Zhang H, Kaushansky K, Zhan H. Cell competition between wild-type and JAK2V617F mutant cells in a murine model of a myeloproliferative neoplasm. Exp Hematol. 2021;100:52-62.

7. Zhan H, Lin CHS, Segal Y, Kaushansky K. The JAK2V617F-bearing vascular niche promotes clonal expansion in myeloproliferative neoplasms. Leukemia. 2018;32:462-9.

8. Lin CHS, Zhang Y, Kaushansky K, Zhan H. JAK2V617F-bearing vascular niche enhances malignant hematopoietic regeneration following radiation injury. Haematologica. 2018;103:1160-8.

9. Mazzeo C, Quan M, Wong H, Castiglione M, Kaushansky K, Zhan H. JAK2V617F mutant endothelial cells promote neoplastic hematopoiesis in a mixed vascular microenvironment. Blood Cells Mol Dis. 2021;90:102585.

10. Sozer S, Fiel MI, Schiano T, Xu M, Mascarenhas J, Hoffman R. The presence of JAK2V617F mutation in the liver endothelial cells of patients with Budd-Chiari syndrome. Blood. 2009;113:5246-9.

11. Rosti V, Villani L, Riboni R, et al. Spleen endothelial cells from patients with myelofibrosis harbor the JAK2V617F mutation. Blood. 2013;121:360-8.

12. Helman R, Pereira WO, Marti LC, et al. Granulocyte whole exome sequencing and endothelial JAK2V617F in patients with JAK2V617F positive Budd-Chiari Syndrome without myeloproliferative neoplasm. Br J Haematol. 2018;180:443-5.

\section{Publisher's Note}

Springer Nature remains neutral with regard to jurisdictional claims in published maps and institutional affiliations.

Ready to submit your research? Choose BMC and benefit from

- fast, convenient online submission

- thorough peer review by experienced researchers in your field

- rapid publication on acceptance

- support for research data, including large and complex data types

- gold Open Access which fosters wider collaboration and increased citations

- maximum visibility for your research: over 100M website views per year

At BMC, research is always in progress.

Learn more biomedcentral.com/submissions 